\title{
Experimental Investigation of Partial Replacement of Cement with Glass Powder and Eggshell Powder Ash in Concrete
}

\author{
Vijayvenkatesh Chandrasekaran*, Vasanth M, Thirunavukkarasu S and Manikanda Prabu T \\ Department of Civil Engineering, St. Josephs College of Engineering and Technology, India
}

Submission: April 30, 2018; Published: June 12, 2018

*Corresponding author: Vijayvenkatesh Chandrasekaran, Department of Civil Engineering, St. Josephs College of Engineering and Technology, Anna University Chennai, India, Email: ramathutham@gmail.com

\begin{abstract}
Cement developed manufacturing is solitary carbon-dioxide emitting sources besides deformation in addition to ablaze of fossil fuel. Emission of greenhouse gages, such as emitted $\mathrm{CO} 2$ to the ambiance. The employment identified the option of by glass fine particles as the incomplete substitute as $0 \%, 20 \%, 30 \%, 40 \%$ and intended for its compressive strength up to $7,14 \& 28$ existence of era and be compared by conventional concrete. Departure squanders fabric failed to emphasize waste can be old additional efficiently and cause an environmental problem. Glass powder and eggshell powder material is very fine powder material obtained as byproducts of glass during sawing and shaping, and not recycling its causes an environmental problem in the world. The option of using it glass ash powder separately as partial replacement of cement on concrete where studied and evaluated based upon \% replacement of cement on concrete where studied and evaluated based upon \% of the partial cement replacement with both glass powder.
\end{abstract}

Keywords: Cement; Glass powder; Eggshell ash powder; Fine aggregate; Coarse aggregate

Abbreviations: BIS: British Standard system; OPC: Ordinary Portland cement; ppm: parts per million

\section{Introduction}

The attention construction of society in use squander or recycled materials in added the concrete is rising since of emphasis located on sustainable construction. The glass (be an still fabric. Which should be recycled [1]. The chemical properties. In adding use waste glass like cullet in glass industrialized waste glass powder in addition to eggshell ash powder crushed into specific size for uses as strengthening cement inside a variety of application [2].

\section{Glass powder}

Manufacturing processes, service industries, and municipal solid wastes are the sources of production of numerous waste materials [3]. Concerns related to disposal of the generated wastes have tremendously increased with the increasing awareness about the environment the use of waste products in concrete not only makes it economical but also helps in reducing disposal problems [4]. Reuse of bulky wastes is considered the best environmental alternative for solving the problem of disposal. One such waste is plastic, which could be used in various applications. Sustainability is an idea for concern for the well being of our planet with continued growth and human development. (the squander glass as of inside and approximately the little shops are crammed full because a waste and willing like the landfill. Squander glass is compressed into particular size intended for use because collective in an assortment of application such as hose filtration, substitute of cement replacement in concrete. The crushed and compressed concrete glass be as well used as the substitute of cement in the concrete manufacture, other than due to its flat and stretched out nature which enhances the reduce inside the workability and credited the fall in compressive strength [5]. A glass is a nebulous material by means of high silica content, thus creation it possibly pozzolanic material when the particle size is less than $75 \mu \mathrm{m}$.study contain exposed that thinly earth glass does not contribute to alkali-silica reaction.

\section{Egg Shell Ash}

The spire of this study is to lime substance composition of the eggshell to discover its suitability of substitute in the concrete [6]. To identification the viability of utilizing the eggshell as cement substitution material. In the direction of study the strength parameters of the eggshell powder diverse specimens and to contrast it with conservative specimens. Calcium wealthy in eggshell ash powder is a fowl waste by means of chemical 


\section{Civil Engineering Research Journal}

composition almost similar to that of limestone [7]. Employ of eggshell waste as an alternative of natural lime to replace cement in concrete can contain reimbursement similar to minimizing the use of cement, conserve usual lime and utilize fabric material [8]. Obviously to a research eggshell squanders age group in India, the united states, the united kingdom is 190000,150000 and 11000 tons per year correspondingly. Eggshell waste can be used as fertilizer, animal feed ingredients, and other such uses. However, the majority of the eggshell waste is deposited as landfills [9]. Eggshell squanders in landfills attract pests due to fond of a casing and causes tribulations linked with a human being health and environment. Few experiments test investigations are conducted to use eggshell waste in civil engineering applications.

\section{Methodology}

Standard concrete cube of size $150 \times 150 \times 150 \mathrm{~mm}$ were cast and tested on 7 days, 14 days and 28days. Partial substitution of glass powder and eggshell ash for cement [10] by $20 \%(15 \%$ glass powder \& 5\% eggshell ash), 30\% (20\% glass powder \& $10 \%$ eggshell ash), $40 \%$ (25\% glass powder \& $15 \%$ eggshell ash) was tried in the control mix and the compressive strength of the adjusted mix proportion was studied.

Standard concrete cylinder size $150 \mathrm{~mm}$ diameter and $300 \mathrm{~mm}$ height were cast and tested on 7 days, 14 days and 28 days [11]. Partial substitution of glass powder and eggshell ash for cement by $20 \%$ ( $15 \%$ glass powder \& $5 \%$ eggshell ash), $30 \%$ (20\% glass powder \& 10\% eggshell ash), 40\% (25\% glass powder \& $15 \%$ eggshell ash) was tried in the control mix and the compressive strength and split tensile strength (cylinders) of the adjusted mix proportion were studied (Figure 1).

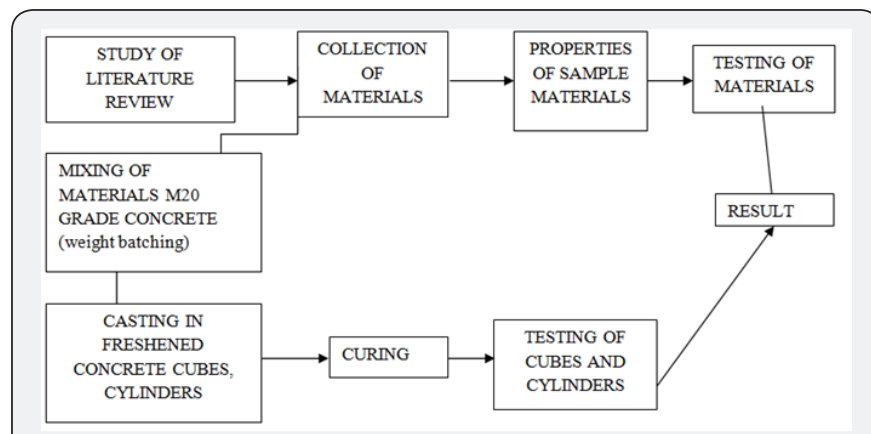

Figure 1: Flow chart

\section{Description of Materials}

\section{Cement}

Ordinary port land cement is the majority ordinary type of cement in all-purpose use approximately the universe, used as a essential element of concrete, mortar, stucco, and most nonspecialty grout [12]. 53 grade (OPC) cement be required to be convened. And refereed BIS specification is 12269-1987 with a designed strength for 7, 28 days being a minimum range of $53 \mathrm{MPa}$ or $530 \mathrm{~kg} / \mathrm{sq} \mathrm{cm}$. More than a few types of port land cement are obtainable by means of the majority widespread ordinary port land cement (OPC) which is grey in color, but a white port land cement is also available [13].

\section{Water}

Potable water (6-7.5ppm) by means of cementitious materials form a cement paste by the procedure of curing process [14]. The cement paste glue the aggregate jointly, closed the voids. Contaminated water used to make concrete be able to reason problems setting or in causing early failure of the structure.

\section{Aggregate}

Aggregates are grainy materials such as $(20 \mathrm{~mm})$ crushed stone sand, gravels, the length of by means of water and Portland cement, are in necessary bonding frictions in concrete [15]. Locally available sand and coarse aggregates were in this experiment [16]. Specific gravity of coarse aggregate is 2.74 .

\section{Glass powder}

The glass is a mixture of a number of metallic silicates, one of which is usually that of an alkali metal [17]. It is an amorphous, transparent or translucent. It may also be considered as a solidified super cooled solution of various metallic silicates having infinite viscosity [18]. The glass powder was obtained by crushing waste glass pieces in a cone crusher mill. In Figure 2, the 425-micron passing friction was used for the experiment.

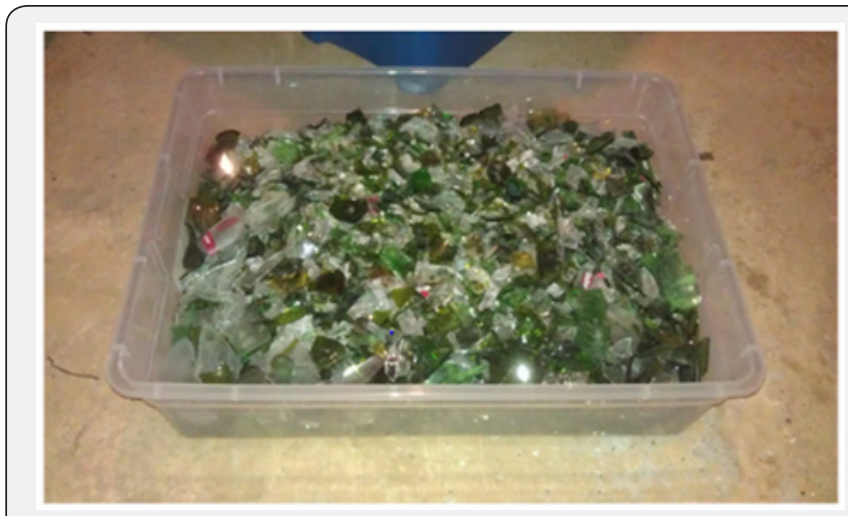

Figure 2: Broken glass.

\section{Egg shell ash}

Eggshell contains $\mathrm{CaCO}_{3}$, the Figure 3 shown as eggshell ash basically contains lime calcium, magnesium carbonate, and protein contents are available [19]. In a lot of other countries, it is conventional practice for eggshell to be dehydrated and use as a source of calcium in creature. The excellence of bright green in eggshell waste is prejudiced very much by the degree of travel around to sunlight, rare water and harsh weather conditions [20]. It is the grained powder ash by means of appropriate quantity which is sieve to the necessary dimension previous to utilize among concrete/mortar. 


\section{Civil Engineering Research Journal}

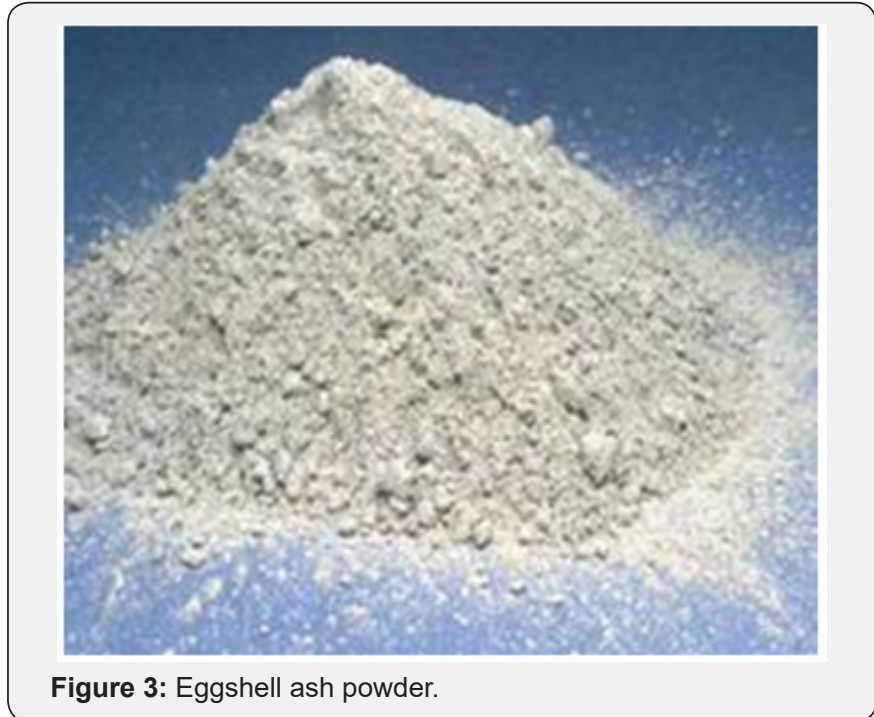

Properties of Concrete

\section{Quality of cement}

Provide the cement be conventional by means of the suitable standard and it have stored properly in dry condition, it must exist for utilize in concrete.

\section{Quality of aggregates}

Superiority quality of aggregates its depends upon its form, size, texture, strength etc. [21]. Determines the strength of concrete its major friction bonds of concrete.

\section{Quality of water}

Frequently the quantity of water is covered by a amount of required conditions status in zonal areas. Clause stating, "the water should be fit for drinking". Humidity (50\%), normal or cold temp (39\%), heavy temp (55-60\%).

\section{Water/cement ratio}

It determine the workability of the concrete so it is very important factor in manufacturing of concrete.

\section{Compaction of concrete}

This test is used to determine the compressive strength of a concrete cube, which has usually been made from the fresh concrete cast in a standard test mold [22]. The value of compressive strength can then be used to assess whether the batch that the concrete cube represents meets the required compressive strength. Following cube manufacture and curing, which should both be closely controlled.

\section{Temperature}

The rate of hydration reaction is temperature reliant. This income that the concrete reserved at superior temperature determination increase strength extra rapidly than a comparable concrete reserved at a lower temperature [23]. Still, the final strength of the obtainable reserved at a higher temperature will be lower.

\section{Fine Glass Powder}

Powder glass beads are made from finely ground glass, the main source being broken and unusable bottles and a great variety of other scrap glasses [24]. Special glasses such as old cobalt medicine bottles, cold cream jars, and many other types of glasses from plates, ashtrays, window panes- to name only a feware occasionally bought new, just for purposes [25]. Waste glass obtainable nearby in Thanjavur shops is been composed. Previous to addition glass powder inside concrete it has designate powder to the preferred dimension in (Figure 4). Crushing period: 30 to 60 minutes.

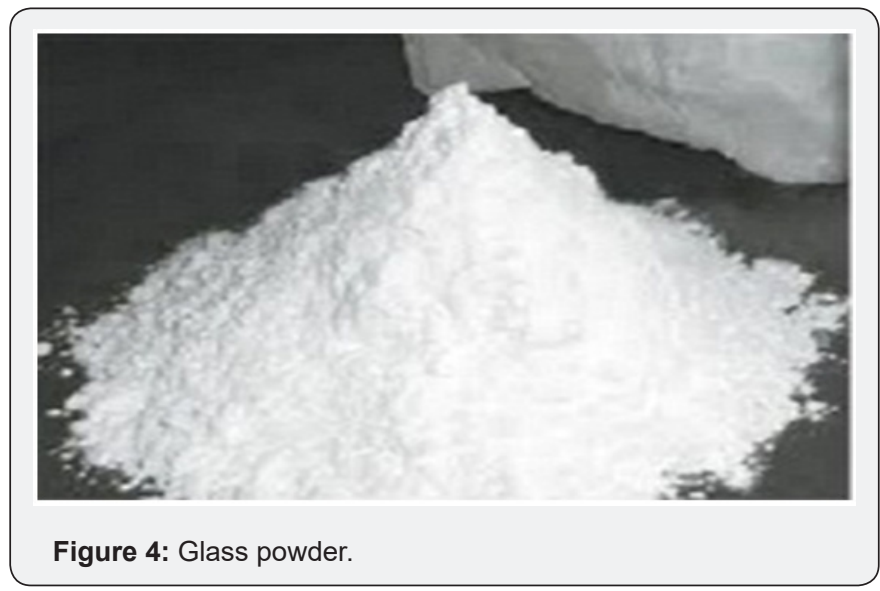

\section{Advantages of glass powder}

- It's economical.

- It's reduced the global warming and environmental friendly.

- It gives more flexibility.

- The glass powder controls the carbon-di-oxide.

- And also reduced the cement consumption.

\section{Egg Shell Ash}

Egg contains several mutually growing layer of $\mathrm{CaCO}_{3}$. Specific gravity egg shell powder ash was 0.84 . Bulk density of egg shell powder was $0.80 \mathrm{gm} / \mathrm{cm}^{3}$.moisture content of a was $1.17 \%$.

\section{Advantages of eggshell powder}

- It's more economical.

- It's most eco-friendly and reduced the global warming.

- Egg shells are high in calcium, magnesium carbonate, and lime content.

- And also a better combination of cement mortar \&concrete admixture.

- 8. Experimental equipment's

\section{Concrete Mixer}

A concrete mixer is a device that homogeneously combines cement, aggregates, such as a sand or gravel land water to form 
concrete. Characteristic concrete mixer uses are developing drum to mix the constituents [26]. Intended for slighter volume works portable concrete mixers are frequently used. An option to a machine in (Figure 5). Is integration concreter cement by hand. This is typically done in a helm barrow. However several companies have lately begun to put up for sale customized traps for this reason. The concrete mixer was invented by Columbus industrialist Gephardt jaeger.

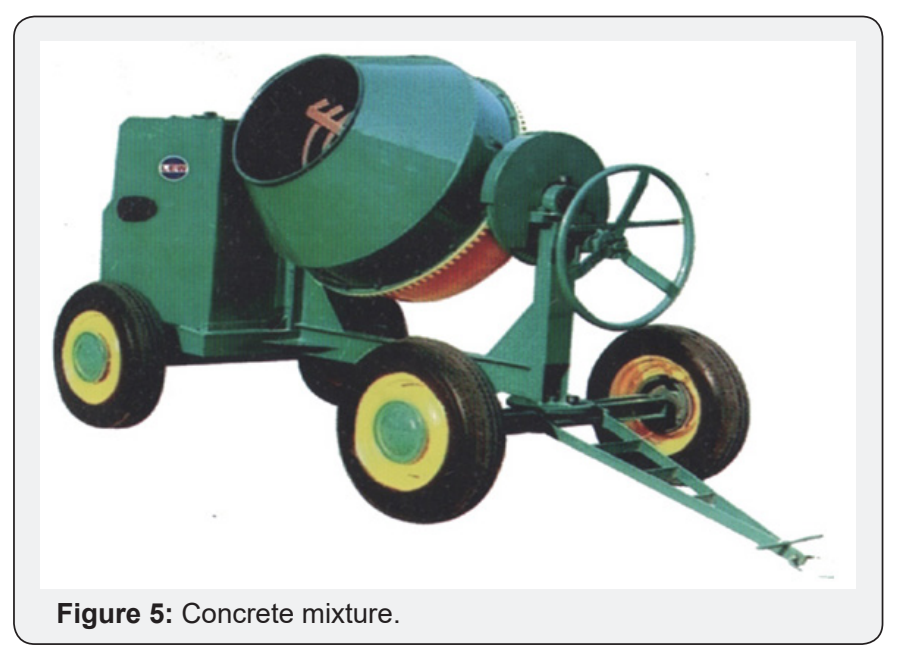

\section{Casting Moulds}

Cubic size: $15^{*} 15^{*} 15 \mathrm{~cm}$. (Figure 6). Cube specimens are crushed after rotating those 90 [27]. To decrease the amount of friction caused by the rough finishing.

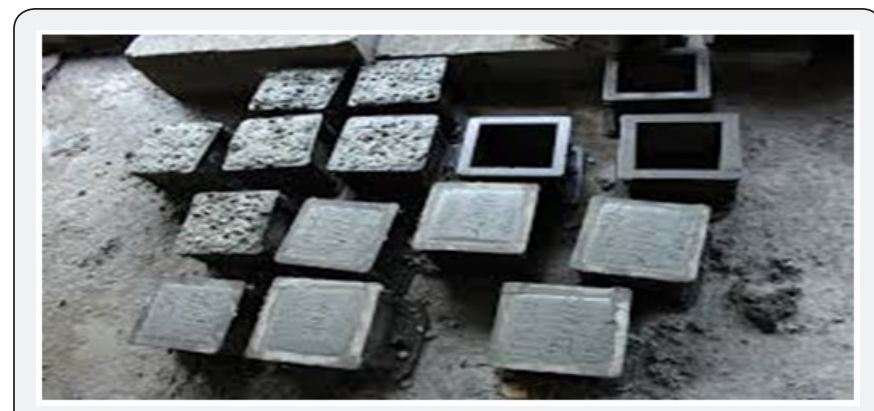

Figure 6: Casting moulds.

\section{Damping Rod}

As per IS: $10086-1982$ the damping rod shall be $16 \pm 0.5 \mathrm{~mm}$ dia and $600 \pm 2 \mathrm{~mm}$ long with a rounded working end and shall be made of HYSD [28] (Figure 7).

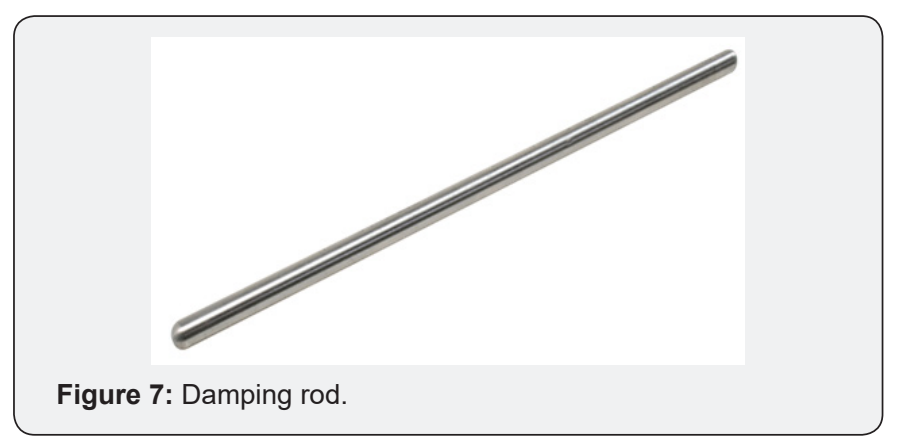

\section{Resources and Place of Work}

The proposed work shall be carried out the laboratories of civil engineering departments of St. Joseph college of engineering and technology, Thanjavur. The routine testing facilities are available in our college itself.

\section{Preparation of specimen}

Batching: Usually batching is done by volume but most stipulation necessitates so as to batching be complete through mass quite than volume. The $\%$ of an accurate dimension of concrete materials.

Quantity of cement: A quantity of cement mix exceeds $=30 \%$ (scale capacity), the measuring accuracy of $1 \%$ of the necessary mass. Intended for minor batches then the measuring accuracy should be within $4 \%$ of the necessary quantity.

Dimensions of aggregates: It fine angular crushed structure, $9.5 \mathrm{~mm}$, and $37.5 \mathrm{~mm}$ diameter. Characteristically most common size of aggregate $(20 \mathrm{~mm})$.

Quantity of water: Is measured inside volumetric quantity amount as 1 -liter water $=1 \mathrm{~kg}$ cement.

Mixing of concrete: Mix design is defined as the development of select appropriate ingredient of concrete and formative their relative proportions [29].

Placing: Cube casting into the molds shall be provided pored in the concrete with a base plate and they shall be as per IS: 10086-1982 [30].

Demolding: Test cubes should be demanded between 16 and 24 hours after they have made. If after this period of time the concrete has not achieved sufficient strength to enable remolding without damaging the cube then the remolding should be delayed for a further 24 hours [31]. When removing the concrete cube from the mold, take the mold apart compressive strength may be reduced.

Curing: Curing is the process in which the concrete is protected from loss of moisture and kept within a reasonable temperature range. This process results in concrete with increased strength and decreased permeability. Curing is also a key player in mitigating cracks, which can severely affect durability.

- It is cured with water. Do not let it dry.

- $\quad$ Dry concrete all reactions stop.

- $\quad$ Keep temperature at moderate level.

\section{Tests on Materials}

\section{Slump cone test}

The concrete slump test is an experiential test that measures the workability of fresh concrete. Additional specifically, it measures the consistency of the concrete in that specific batch. (M20, M25, M30). This test is perform to check the consistency of freshly concrete slump $0-25 \mathrm{~mm}$, low workability mixes $10-40 \mathrm{~mm}$, 


\section{Civil Engineering Research Journal}

medium workability mixes; $50-90 \mathrm{~mm}$ for normal reinforcement concrete placed with vibration [32], high workability concrete; $>100 \mathrm{~mm}$

\section{Mix proportion}

Grade: M20

$\mathrm{w} / \mathrm{c}$ ratio: 0.5

The slump value for $\mathrm{w} / \mathrm{c}$ ratio of 0.5 is $70 \mathrm{~mm}$

\section{Standard consistency test}

Prepare a paste of weighed quantity of cement (approx. 400 gems) with the weighed quantity of water (start from 20\%-25\%) taking care that mixing (gauging) remains between 3 to 5 minutes and mixing shall be completed before any signs of setting becomes visible. Fill the vacant mold with the paste, the mould should rest on non-porous base. Place the mold under Vicat apparatus. The plunger attached to a movable rod is gently lowered on the paste. Settlement of a plunger is noted, penetration from the bottom is equal to the difference of mold height and settlement of plunger. If penetration of the plunger is within $5-7 \mathrm{~mm}$ from the bottom, then water added is correct. Otherwise, water is added and replace is repeated.

\section{Calculation}

Water content $=$ weight of cement $\times \%$ of water content

$400 \times 25 / 100=100 \mathrm{ml}$

$400 \times 27 / 100=108 \mathrm{ml}$

Standard consistency of cement $=30 \%$

\section{Specific gravity test on fine and coarse aggregate}

Dry the pycnometer and weight it with its limit (W1). Obtain about 200gms of oven sand passing through $4.75 \mathrm{~mm}$ sieve into the pycnometer and weight again (W2). Thoroughly dry the pycnometer from outside and weight it (W3). Weight the pycnometer after drying it on the outside thoroughly (W4). Do another time the procedure for three samples (Table 1).

Table 1: Specific gravity of fine aggregate.

\begin{tabular}{|c|c|}
\hline Weight & Weight in Grams \\
\hline $\mathrm{W}_{1}$ & 628 \\
\hline $\mathrm{W}_{2}$ & 1663 \\
\hline $\mathrm{W}_{3}$ & 2179 \\
\hline $\mathrm{W}_{4}$ & 1524 \\
\hline
\end{tabular}

Formula used

$G=W 2-W 1 /(W 2-W 1)-(W 3-W 4)$

Where,

W1=Empty weight of pycnometer
W2=Weight of pycnometer + oven dry soil

W3=Weight of pycnometer + oven dry soil + water

W4=Weight of pycnometer + water (Table 2) specific gravity of fine aggregate

Table 2: Specific gravity of coarse aggregate.

\begin{tabular}{|c|c|}
\hline Weight & Weight in Grams \\
\hline $\mathrm{W}_{1}$ & 700 \\
\hline $\mathrm{W}_{2}$ & 1350 \\
\hline $\mathrm{W}_{3}$ & 1950 \\
\hline $\mathrm{W}_{4}$ & 1540 \\
\hline
\end{tabular}

\section{Calculation}

$G=1663-628 /(1663-628)-(2179-1524)$

$G=2.65$

Specific gravity of river sand $g=2.65$

\section{Calculation}

$G=1350-700 /(1350-700)-(1950-1540)$
$\mathrm{G}=2.8$

Specific gravity of coarse aggregate $\mathrm{g}=2.8$

\section{Fineness modulus test on river sand and coarse aggregate}

For a $500 \mathrm{gms}$ of range oven dry soil example, grain size allocation has to be deliberate. Obtain the soil sample into $75 \mu$ sieve (Table 3 \& 4). 


\section{Civil Engineering Research Journal}

Table 3: Fineness modulus of river sand.

\begin{tabular}{|c|c|c|c|c|}
\hline Is-Sieve No.(mm) & Weight Retained (gms) & \% Weight Retained & $\begin{array}{c}\text { Cumulative \% Weight } \\
\text { Retained }\end{array}$ & \% Passing \\
\hline 4.75 & 60 & 1.2 & 1.2 & 98.8 \\
\hline 2.36 & 535 & 10.7 & 11.9 & 88.1 \\
\hline 1.188 & 1100 & 22 & 33.9 & 66.1 \\
\hline $600 \mu$ & 1230 & 24.6 & 58.5 & 41.5 \\
\hline $300 \mu$ & 1430 & 28.6 & 87.1 & 12.9 \\
\hline $150 \mu$ & 235 & 4.7 & 91.8 & 8.2 \\
\hline $75 \mu$ & 265 & 5.3 & 97.1 & 100 \\
\hline Pan & 145 & 2.9 & & 0 \\
\hline
\end{tabular}

Table 4: Fineness modulus of coarse aggregate.

\begin{tabular}{|c|c|c|c|c|}
\hline Is- Sieve No & Weight Retained (gms) & \% of Weight Retained & $\begin{array}{c}\text { Cumulative \% Weight } \\
\text { Retained }\end{array}$ & \% Passing \\
\hline 40 & - & - & - & - \\
\hline 25 & 0.055 & 1.1 & 1.1 & 74.4 \\
\hline 20 & 1.255 & 24.5 & 25.6 & 29.8 \\
\hline 16 & 2.23 & 44.6 & 90.2 & 4.4 \\
\hline 12.5 & 1.27 & 25.4 & 98.6 & 1.6 \\
\hline 10 & 0.14 & 2.8 & 100 & 0 \\
\hline
\end{tabular}

\section{Calculation}

Fineness modulus $=$ cumulative $\%$ weight retained $/ 100$

Fineness modulus $=481.5 / 100$

Fineness modulus $=4.81$

\section{Calculation}

Fineness modulus $=$ cumulative $\%$ weight retained

Fineness modulus $=390.7 / 100$
Fineness modulus $=3.9$

\section{Water absorption test}

The fine aggregate passing through is $4.75 \mathrm{~mm}$ sieve is taken about $1 \mathrm{~kg}$ and dehydrated inside an oven at a high temperature of $110^{\circ} \mathrm{c} \pm 5^{\circ} \mathrm{c}$ for after 24 hours and cooled to room temperature. Its weight is taken as (W1 g).the dried fine aggregate is immersed in clean water at a temperature $27^{\circ} \mathrm{C} \pm 2^{\circ} \mathrm{c}$ for 24 hours. The fine aggregate is removed from the water. Within three minutes from the removal of water, the weight of fine aggregate W2 is found out. The above procedure is repeated for various samples (Table 5-11).

Table 5: Water absorption.

\begin{tabular}{|c|c|c|c|c|}
\hline Sample Number & $\begin{array}{l}\text { Weight of Oven Dried } \\
\text { Specimen }\left(W_{1}\right) g\end{array}$ & $\begin{array}{l}\text { Weight of Saturated } \\
\text { Specimen }\left(W_{2}\right) g\end{array}$ & $\begin{array}{l}\text { Weight of Absorbed } \\
\qquad W_{3}=\left(W_{2}-W_{1}\right) g\end{array}$ & $\begin{array}{c}\% \text { of Water } \\
\text { Absorption }=\left(W_{3} /\right. \\
\left.W_{1}\right) \times 100\end{array}$ \\
\hline 1 & 0.955 & 1.01 & 0.015 & 1.5 \\
\hline
\end{tabular}

The percentage of water absorption is $1.5 \%$.

Table 6: Physical properties of cement.

\begin{tabular}{|c|c|}
\hline Physical Properties & Value \\
\hline Standard consistence of cement & $30 \%$ \\
\hline Fineness of cement & $1.33 \%$ \\
\hline
\end{tabular}

Table 7: Physical properties of fine aggregate.

\begin{tabular}{|c|c|}
\hline Physical Properties & Value \\
\hline Specific gravity & 2.54 \\
\hline Bulk relative density $\left(\mathrm{kg} / \mathrm{m}^{3}\right)$ & 1460 \\
\hline Fineness modulus & 4.81 \\
\hline
\end{tabular}




\section{Civil Engineering Research Journal}

Table 8: Physical properties of coarse aggregate.

\begin{tabular}{|c|c|}
\hline Physical Properties & Value \\
\hline Specific gravity & 2.52 \\
\hline Bulk relative density $\left(\mathrm{kg} / \mathrm{m}^{3}\right)$ & 1691 \\
\hline Fineness modulus & 3.9 \\
\hline
\end{tabular}

Table 9: Physical properties of glass powder.

\begin{tabular}{|c|c|}
\hline Physical Properties & Values \\
\hline Specific gravity & 2.6 \\
\hline Fineness passing $150 \mu \mathrm{m}$ & 99.5 \\
\hline Fineness passing $90 \mu \mathrm{m}$ & 98 \\
\hline
\end{tabular}

Table 10: Chemical properties of glass powder.

\begin{tabular}{|c|c|}
\hline Chemical Pproperties & Values \\
\hline $\mathrm{Ph}$ & 10.25 \\
\hline Color & Grayish white \\
\hline
\end{tabular}

Table 11: Physical properties of egg shell ash.

\begin{tabular}{|c|c|}
\hline Physical Property & Values \\
\hline Specific gravity & 0.85 \\
\hline Moisture content & 1.18 \\
\hline Bulk density $\left(\mathrm{g} / \mathrm{m}^{3}\right)$ & 0.8 \\
\hline Particle density $\left(\mathrm{g} / \mathrm{m}^{3}\right)$ & 1.012 \\
\hline Porosity $(\%)$ & 22.4 bet \\
\hline Surface area $\left(\mathrm{m}^{2} / \mathrm{g}\right)$ & 21.2 \\
\hline
\end{tabular}

\section{Formula used}

Percentage of water absorption $=(W 2-W 1) \times 100 / W 1$

\section{Tests Results on Concrete}

\section{General}

A concrete test is performed to study additional concerning the property of a specific example of concrete [32]. A number of dissimilar tests can be performed on concrete in cooperation, on a job location, and in a laboratory. Because concrete is significant structural elements, testing is binding in many regions of the world, and construction companies must be used refer documentation of their testing and results when asked to accomplish so by government legislature [33].

\section{Concept of mix design}

- The grade was M20.

- The combination cement contend of $6 \mathrm{~kg}$.

- The water cement ratio is 0.53 . The replacement levels of cement, glass powder \&egg shell powder were used in terms of $20 \%, 30 \%, 40 \%$.

\section{Workability}

Slump test the workability of all concrete mixture was determine through slump test utilizing a metallic slump mould [34]. The difference in level between the height of mould and that of highest point of the subsided concrete was measured and reported as slump. This test is performed to check the consistency of freshly made concrete [35]. Consistency is a term very closely related to workability.

\section{Tests on Hardened Concrete}

\section{Compressive test}

The determination of compressive strength is primarily mean to withstand compressive stress as concrete is strong in compression .higher the compressive strength better is the durability and bond strength which is very important in quality control of concrete. Select a suitable proportion of cement, fine aggregate and coarse aggregate. The mould greased with oil and the concrete was compacted in it with the tamping rod and trowel. The mould after filling with concrete was placed on placed on the vibration table. Number of concrete are prepared like this were placed for curing which are taken out at different time periods and then placed in compression testing machine. The load was gradually applied and the value at which the maximum failure was noted and the values are tabulated [36] (Table 12) (Figure 8).

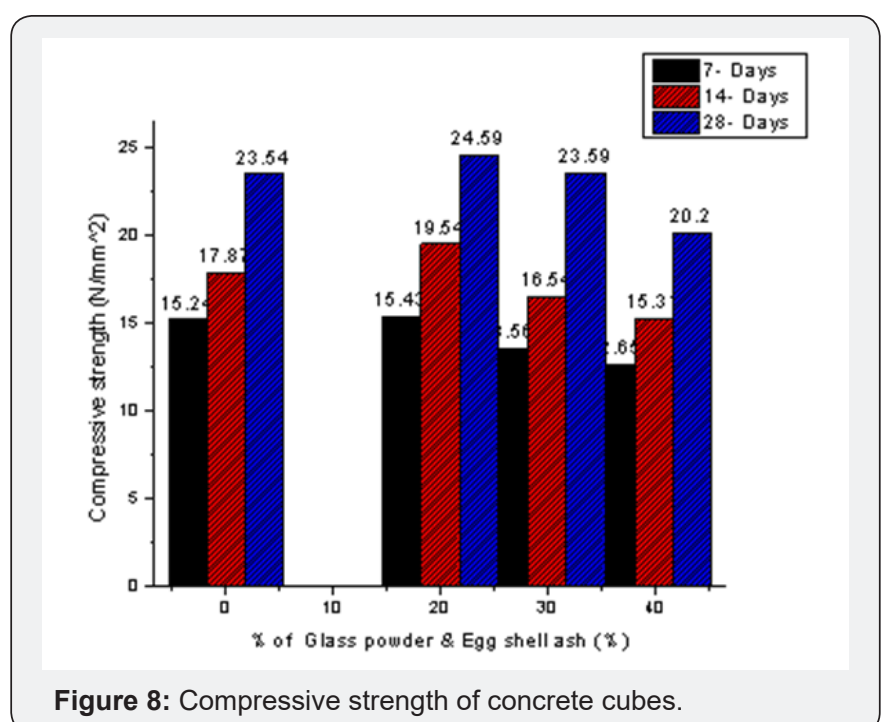

Table 12: Compressive strength of the concrete cube (N/mm2)

\begin{tabular}{|c|c|c|c|}
\hline $\begin{array}{c}\text { \% of Glass } \\
\text { Powder \& Egg } \\
\text { shell Ash }\end{array}$ & \multicolumn{3}{|c|}{ Compressive Strength $\left(\mathrm{N} / \mathbf{m m}^{2}\right)}$. \\
\hline & 7days & $\mathbf{1 4}$ days & $\mathbf{2 8}$ days \\
\hline $0 \%$ & 15.24 & 17.87 & 23.54 \\
\hline $20 \%$ & 15.43 & 19.54 & 24.59 \\
\hline $30 \%$ & 13.56 & 16.54 & 23.59 \\
\hline $40 \%$ & 12.65 & 15.31 & 20.2 \\
\hline
\end{tabular}

\section{Apparatus required}

- $\quad$ Compressive testing machine

- $\quad$ Concrete cube mould $(150 \mathrm{~mm} \times 150 \mathrm{~mm} \times 150 \mathrm{~mm})$

- $\quad$ Damping rod 


\section{Civil Engineering Research Journal}

- $\quad$ Tray

- $\quad$ Trowel

\section{Split tensile test}

- Cylinder splitting test: this is also sometimes referred as, "Brazilian test"

- This test developed in Brazil in 1943

- 14.1. Splitting tensile strength test on concrete cylinders

- Splitting tensile strength test on the concrete cylinder is a technique to decide the tensile strength of concrete.

- The concrete is extremely feeble in tension due to its brittle nature and is not predictable to resist the direct tension.

- The concrete develops cracks when subjected to tensile forces. To determine the splitting tensile of concrete (Figure 9) (Table 13).

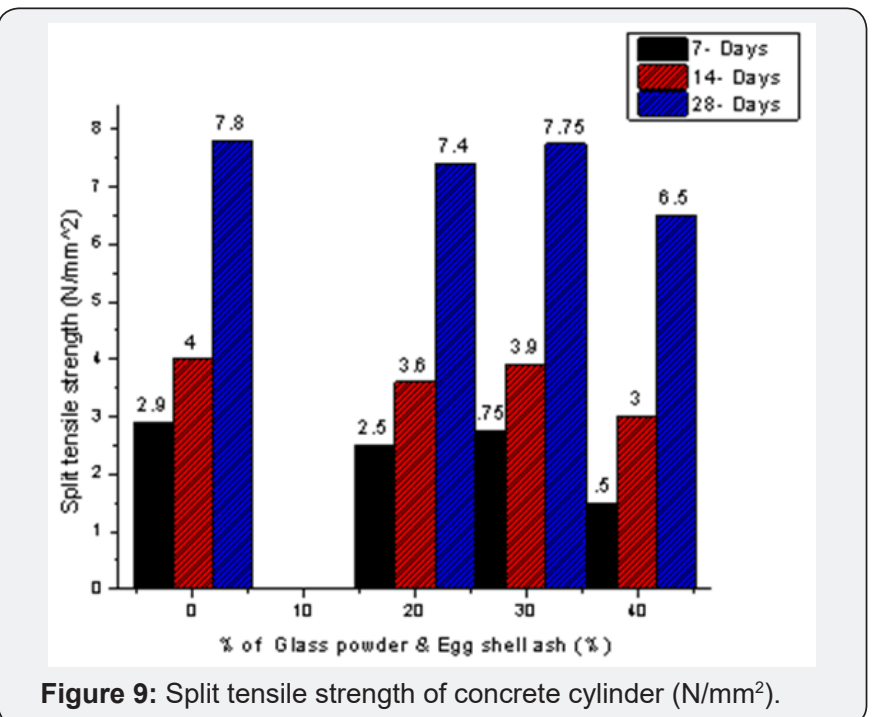

Table 13: Split tensile strength of concrete cylinder $\left(\mathrm{N} / \mathrm{mm}^{2}\right)$.

\begin{tabular}{|c|c|c|c|}
\hline $\begin{array}{c}\text { \% of Glass } \\
\text { Powder \& Egg } \\
\text { Shell Ash }\end{array}$ & \multicolumn{3}{|c|}{ Split Tensie Strength (N/mm ${ }^{2}$. } \\
\hline & 7days & 14 days & 28 days \\
\hline $0 \%$ & 2.9 & 4 & 7.8 \\
\hline $20 \%$ & 2.5 & 3.6 & 7.4 \\
\hline $30 \%$ & 2.75 & 3.9 & 7.75 \\
\hline $40 \%$ & 1.5 & 3 & 6.5 \\
\hline
\end{tabular}

Results

The result of the variation of compressive strength and split tensile strength of concrete produced by replacing cement with glass powder with eggshell ash for 7, 14 \& 28 days [37]. From the above-said combinations, $30 \%$ (20\% glass powder and $10 \%$ eggshell ash) achieve good workability, compressive strength and split tensile strength of concrete than the other combinations. So it is optimum and recommended for the structural purposes.

\section{Conclusion}

From our investigation for M20 grade concrete by replacing $40 \%$ also it attain $20 \mathrm{~km} / \mathrm{m} 3$.so we can make it as a practice by replacing $40 \%$ in all conventional buildings. It also makes it a economical and eco-friendly building [38]. The above-mentioned work of various researchers and our present experimental work, it is clear that glass powder and eggshell ash can be used as a partial replacement of cement in concrete because of its increased workability, strength parameters like compressive strength and split tensile strength [39]. As for disposal, utilization of waste glass powder and eggshell ash in concrete will not only provide economic, it will also help in reducing disposal problems.

\section{Acknowledgement}

Partial replacement of cement with glass powder and eggshell powder ash in concrete these paper works fully ready to worn risks not supporting any funding in the institute. It's highly suggested the partial replacement of $20 \%$ of glass powder and $15 \%$ of eggshell ash powder in concrete. It better results in compared the normal concrete.

\section{References}

1. Priemus H (1999) Sustainable cities: how to realize an ecological breakthrough: a Dutch approach. International Planning Studies 4(2): 213-236.

2. Zhang S (2015) Waste glass as partial binder precursor and fine aggregate replacement in alkali activated slag/fly ash system.

3. Sharholy M, Ahmad K, Mahmood G, Trivedi RC (2008) Municipal solid waste management in Indian cities-A review. Waste management 28(2): 459-467.

4. Siddique R, Khatib J, Kaur I (2008) Use of recycled plastic in concrete: a review. Waste management 28(10): 1835-1852.

5. Somayaji S (2011) Civil engineering materials. Pearson Education India.

6. Gebregziabhier TT (2009) Durability problems of 20th century reinforced concrete heritage structures and their restorations (Doctoral dissertation, Universitat Politècnica de Catalunya. Escola Tècnica Superior d'Enginyers de Camins, Canals i Ports de Barcelona. Departament d'Enginyeria de la Construcció, 2009 (Advanced Masters in Structural Analysis of Monuments and Historical Constructions (SAMHC))).

7. Yamaguchi N, Nagaishi M, Kisu K, Nakamura Y, Ikeda K (2013) Preparation of monolithic geopolymer materials from urban waste incineration slags. Journal of the Ceramic Society of Japan 121(1417): 847-854.

8. Handy RL (1995) The day the house fell. American Society of Civil Engineers.

9. Quina MJ, Soares MA, Quinta-Ferreira R (2016) Applications of industrial eggshell as a valuable anthropogenic resource. Resources, Conservation and Recycling.

10. Matos AM, Sousa-Coutinho J (2012) Durability of mortar using waste glass powder as cement replacement. Construction and Building Materials 36: 205-215. 


\section{Civil Engineering Research Journal}

11. Faisal FW, Ashour SA (1992) Mechanical properties of high-strength fiber reinforced concrete. ACI Material Journal 89(5): 449-455.

12. Charvát P (2003) Mesopotamia before history. Routledge.

13. Bensted J (2002) Calcium aluminate cements. Structure and Performance of Cements 2: 114-138.

14. Sabai MM, Cox MGDM, Mato RR, Egmond ELC, Lichtenberg JJN (2013) Concrete block production from construction and demolition waste in Tanzania. Resources, Conservation and Recycling 72: 9-19.

15. Ohama Y (1978) Development of concrete-polymer materials in Japan. In Second Int. Congress on Polymers in Concrete. The University of Texas, pp. 121-137.

16. Rahal K (2007) Mechanical properties of concrete with recycled coarse aggregate. Building and environment 42(1): 407-415.

17. Idota Y, Kubota T, Matsufuji A, Maekawa Y, Miyasaka T (1997) Tin-based amorphous oxide: a high-capacity lithium-ion-storage material. Science 276(5317): 1395-1397.

18. Martinez LM, Angell CA (2001) A thermodynamic connection to the fragility of glass-forming liquids. Nature 410(6829): 663-667.

19. Oliveira DA, Benelli P, Amante ER (2013) A literature review on adding value to solid residues: egg shells. Journal of cleaner production 46 42-47.

20. Witoon $\mathrm{T}$ (2011) Characterization of calcium oxide derived from waste eggshell and its application as $\mathrm{CO}_{2}$ sorbent. Ceramics International 37(8): 3291-3298.

21. Hartley A (1974) A review of the geological factors influencing the mechanical properties of road surface aggregates. Quarterly Journal of Engineering Geology 7(1): 69-100.

22. Morel JC, Pkla A, Walker P (2007) Compressive strength testing of compressed earth blocks. Construction and Building Materials 21(2): 303-309.

23. Villa J (2012) Advancements in sustainable concrete practices and their potential impact on design and construction. Illinois Institute of Technology.

24. Ackam NLT (2013) Amplifying the Ghanaian Bead through Publication Design (Doctoral dissertation).

25. Lawrence S (2006) Artifacts of the modern world. Archaeology in Practice: A student guide to archaeological analyses pp. 362-388.
26. Ouchi M, Nakamura SA, Osterberg T, Hallberg S, Lwin M (2003) Applications of self-compacting concrete in Japan, Europe and the United States. Kochi University of Technology, Kochi, Japan.

27. Ozkul MH, Dogan UA, Cavdar Z, Saglam AR, Parlak N (1999) Properties of fresh and hardened concretes prepared by new generation superplasticizers. Creating with Concrete, pp. 467-474.

28. Patiyal N, Kumar J, Sharma AK (2016) Experimental Study on Geopolymer Concrete with Partial Replacement of Fine Aggregate with Foundry Sand. Environment, pp. 133-138.

29. Day K (2003) Concrete Mix Design, Quality Control and Specification (with CD ROM). CRC Press.

30. Nirmalkumar K, Sivakumar V (2008) Corrosion studies on concrete using treated and untreated textile effluent and impact of corrosion inhibitor. Journal of sustainable development 1(3): 68 p.

31. Chen Y, Xia C, Shepard Z, Smith N, Rice N, et al. (2017) Self-Healing Coatings for Steel-Reinforced Concrete. ACS Sustainable Chemistry \& Engineering 5(5): 3955-3962.

32. Panesar MK (2016) Study on the performance of concrete using hypo sludge and polypropylene fiber (Doctoral dissertation, Punjab Agricultural University, Ludhiana)

33. Goldstein K, Scheerer M (1941) Abstract and concrete behavior an experimental study with special tests. Psychological monographs 53(2): i-151.

34. McCabe S (2014) Quality Improvement Techniques in Construction: Principles and Methods. Routledge.

35. Ferraris CF (1999) Measurement of the rheological properties of high performance concrete: state of the art report. Journal of research of the national institute of standards and technology 104(5): 461.

36. Koehler EP, Fowler DW (2003) Summary of concrete workability test methods.

37. Hoover CG, Bažant ZP, Vorel J, Wendner R, Hubler MH (2013) Comprehensive concrete fracture tests: description and results. Engineering fracture mechanics 114: 92-103.

38. Bartos P (1999) Fresh concrete: properties and tests. Vol 38. Elsevier.

39. Wallevik JE (2006) Relationship between the Bingham parameters and slump. Cement and Concrete Research 36(7): 1214-1221.

\section{Your next submission with Juniper Publishers will reach you the below assets}

- Quality Editorial service

- Swift Peer Review

- Reprints availability

- E-prints Service

- Manuscript Podcast for convenient understanding

- Global attainment for your research

- Manuscript accessibility in different formats

( Pdf, E-pub, Full Text, Audio)

- Unceasing customer service

Track the below URL for one-step submission https://juniperpublishers.com/online-submission.php 